\title{
Spirituality in pediatric practice
}

Marlene Pereira Garanito ${ }^{1}$, Marina Rachel Graminha Cury ${ }^{2}$

\section{Abstract}

\section{Spirituality in pediatric practice}

The theme of palliative care in pediatric practice represents a relevant topic for discussion in the context of bioethics. In this respect, we seek to emphasize that the spiritual dimension is an integral part of the care of pediatric patients, and therefore health teams need to be able to embrace this transcendent movement and be attentive to the spiritual needs of pediatric patients, as well as their caregivers.

Keywords: Spirituality. Brazil. Palliative care. Pediatrics.

\section{Resumo}

A espiritualidade na prática pediátrica

O tema dos cuidados paliativos na prática pediátrica ocupa relevante espaço de discussão no contexto da bioética. Nesse aspecto, destacamos que a dimensão espiritual é parte integrante do paciente pediátrico e que, portanto, a equipe de saúde precisa estar apta a acolher esse movimento de transcendência e atenta às necessidades espirituais desses pacientes, bem como de seus responsáveis.

Palavras-chave: Espiritualidade. Brasil. Cuidados paliativos. Pediatria.

\section{Resumen}

\section{La espiritualidad en la práctica pediátrica}

El tema de los cuidados paliativos en la práctica pediátrica ocupa un espacio relevante de discusión en el contexto de la bioética y, en este sentido, hacemos hincapié en que la dimensión espiritual es una parte integrante de los pacientes pediátricos y por lo tanto el equipo de salud debe ser capaz de acoger este movimiento de trascendencia y permanecer atento a las necesidades espirituales de los pacientes pediátricos, así como a las de sus padres.

Palabras-clave: Espiritualidad. Brasil. Cuidados paliativos. Pediatría.

1. Mestranda marlene.garanito@ig.com.br - Centro Universitário São Camilo, São Paulo 2. Especialista marinagraminha@yahoo.com.br - Instituto da Criança e do Serviço de Onco-Hematologia do Instituto da Criança (HCFMUSP), São Paulo/SP, Brasil.

Correspondência

Marlene Pereira Garanito - Rua Venâncio Aires, 315 CEP 05024-030. São Paulo/SP, Brasil.

Declaram não haver conflito de interesse. 
The dilemmas related to the mortalityin pediatric practice provide significant scope for discussion in the context of bioethics ${ }^{1}$. In childhood, the tragic situation of having to address the definition of terminal illness is more complex than in adults, because the determination of irreversibility in children is a more arduous process that demands longer. This fact is especially relevant in Latin America, where medicine is characterized by a strong paternalistic component associated with the traditional concept of maintaining life at any price, from the point of view of both civil society and medical practitioners ${ }^{2}$.

In this context, another major issue refers to palliative care for this age group. By definition, such care comprises the efficient and holistic care provided to children, in a physical, mental and spiritual context, as well as the support offered to their family as a whole. In this regard, we highlight the attention given to spirituality, which becomes increasingly necessary in the practice of health care, and is recognized as a source of well-being and quality of life when approaching death. Therefore, it is essential that health professionals are able to accommodate this transcendent movement, at this stage of human existence $^{3}$.

\section{Brief historical context}

In the late twentieth century, specifically in the 1970s, technological developments overvalued scientific aspects at the expense of humanistic aspects, leading medical education to not only remove the study of humanities from the curriculum, but also to discredit any attempt to resume this direction ${ }^{4}$. Unfortunately, the values inherent in interdisciplinary medicine, religion, spirituality, philosophy and anthropology were forgotten. However, it is in this context that contemporary medicine deserves profound consideration, since these interactions are reflected in the doctor-patient relationship.

It is well known that patients, regardless of their age, not only want to but should receive humane treatment, not only focused on dealing with their illness, and should be observed from all apects, among which spirituality is included. Therefore, to ignore this dimension, among others, makes the management of patients incomplete and ineffective ${ }^{3}$.

The attention to spirituality is part of what is known as palliative care. The term "palliative" comes from the Latin pallium, a robe worn by pilgrims to protect themselves from bad weather during their journeys to the shrines. Analogically, palliative care is intended to protect the sick person during their last phase of life ${ }^{5}$. In pediatrics, this care is focused on children and adolescents, and aimed at the whole family and built upon a good relationship between professionals, patients and their guardians. This care should assess each patient and their family individually, respecting their spirituality and values and facilitating communication. Such care should also be extended after death, during the family's period of mourning ${ }^{6}$.

In South America, palliative care emerged in the 1980s, in Argentina and Colombia. In Brazil, the first service of this kind was established in 1983, in the south of the country. In 1997, the Brazilian Association of Palliative Care ( $A B C P$ ) was founded, and, in 2005, the National Academy of Palliative Care (ANCP) was established. In 2009, for the first time in the history of Brazilian medicine, the Federal Council of Medicine (CFM) included palliative care as a fundamental principle in the new Code of Medical Ethics (CEM). Despite the fact that palliative medicine was recognized in 2012 as a medical discipline, there is still a long and arduous way to go for this specialty ${ }^{7,8}$, given that, to date, Brazil has no palliative care structure to match the demand, from both a quantitative and qualitative perspective ${ }^{5}$. It is essential that medical schools understand the real importance of this new medical specialty and can establish better strategies for teaching end-oflife caregiving, a subject that, in general, has been neglected in the undergraduate courses of Brazilian medical schools ${ }^{9}$. In addition, the promotion of medical residency programs, specialization courses and good graduate programs in this field of medicine is essential.

This scenario indicates the urgent need to spread the fundamental concepts of palliative care in our country, and to make efforts to establish health policies focused on dealing with the end-of-life ${ }^{5}$.

\section{Spirituality in Pediatrics}

The medical option requires a vocation primarily directed to taking care of others, and this responsibility for those who are vulnerable is the spiritual challenge of bioethics and caring especially for pediatricians, who look after patients and their families. Medical procedures deal not only with life, human dignity and health, but also with terminal illness and the death of others. In this context, bonds of trust, compassion and understanding established with the patients and their families, added 
to respect for their spiritual values, are essential to professional practice ${ }^{10}$.

Spirituality can be understood as the search for the significance and meaning of life in dimensions that transcend the tangible, leading human feelings to experience something greater than their very existence, which may or may not be related to a formal religious practice. It is undeniable that the spiritual dimension and its relationship with health, is becoming a clear paradigm to be established in daily medical practice and should be regarded as a genuine experience for both the person who is cared for and for those who care. Hence the extreme importance of building environments favourable for dialogue ${ }^{11}$.

Children, in particular, do not distinguish spirituality from religion, but their sense of spirituality or their involvement in a religious community can promote a positive strategy in coping with the disease ${ }^{4}$.

In daily practice, it seems clear that spirituality helps some patients - especially teenagers - to deal with illnesses, especially those that present a risk of death, and terminal situations. To facilitate this aid, it is essential that health professionals be alert to patients feedback and develop communication skills and the ability to evaluate the spiritual dimension of those under their care. In their narrative, patients describe the experience of their illness and give meaning to it through spiritual connections and relationships, which is demonstrated through a desire to relate, to establish links within the hospital with the staff and other patients, and to continue being what they were before hospitalization ${ }^{12}$.

Hospitalized children of school going age, for example, are able to reveal important aspects of spirituality that they use as support during traumatic events such as illness and hospitalization. The experience of suffering helps the child approach the spiritual dimension, through which they find the strength to be hopeful about the future ${ }^{12}$.

The spiritual approach in pediatricians' working process consists of expanding their perspective of children and their families, respecting those who are vulnerable and reviewing concepts regarding health and illness, and the doctor-patient relationship ${ }^{4}$.

In this sense, a service that could help professionals working in this area is called the chaplaincy. It is known that providing religious access to all denominations in civil and military establishments, as well as in public or private hospitals, offering religious and spiritual care to hospitalised patients, was assured by Law no. 9982/2000. And, among the services that provide this type of care to infirms in hospitals in public or private hospitals, the hospital religious service, or chaplaincy, held by chaplains stands out ${ }^{13}$.

In countries such as the United States and England, the chaplain is part of the multidisciplinary team of patient care, and has access to the patients' medical records, which records their visits, assessments, interventions and other spiritual assistance activities. If this is a routine action in hospitals in these countries, the same is not true in Brazil, where chaplains still seek due recognition for their profes$\operatorname{sion}^{14}$. In our daily practice, when we consider the entries in the medical records, we note that the mention of this type of care is virtually non-existent. It is known that the medical records brings together all the information on the health status of the patient, that is, the history record and all the care and assistance provided to the patient. It is characterized by being a communication vehicle among members of the health team; so its correct completion by the team (doctor, nurse, psychologist, social worker, dietician, occupational therapist) is critical for making appropriate clinical decisions.

In our field, spiritual care is provided by the chaplain and volunteers, who have no access to medical records, which hinders the raising of this issue within the multidisciplinary team. In this sense, we wish to point out that this document should include not only the clinical aspects, the presence or absence of disease, but also preventive issues, socio-economic difficulties, conflicts of interest, coexistence and beliefs, that need - yes - to be registered with a view to better care for patients and their families.

\section{Considerations about the psychological constitution of the child}

Although several authors have contributed to the understanding of children's' and adolescents' spirituality by addressing the stages of cognitive development ${ }^{15,16}$, the emphasis in these stages does not respond to the issues raised daily by health professionals who attend to this age group: would children's spirituality be an imitation of what they see in adults or something that they create themselves? Would the concept that children have of death and transcendence be the same as adults? How would one approach this matter with a child?

These questions help emphasize that a child's spiritual dimension is not related only to their stage 
of cognitive development, and that is what psychoanalysis can contribute to the debate, since it places the child as the subject of the unconscious, from when they start to speak. That is to say that the conception of the child's spirituality, despite being influenced by those who participate in their care, is unique and directly related to their own subjective nature - and is not very different from an adult perspective.

According to Freud $^{17}$, the subject's relationship with religion follows the child prototype; that is, their relationship with God is nothing more than a repetition of the relationship with their own parents and comes from the state of helplessness they feel in situations beyond their control, such as the inevitable frustrations of life in society and the very force of nature. In this context religious ideas, that emerged from a human need, are teachings and assertions about facts and conditions of an external (or internal) reality that tell us something we did not find ourselves and, therefore, demand our trust.

Freud $^{17,18}$ sees in the child the paradigm of mankind's relationship with religion and, in this regard, points out that, despite the differences between children and adults, our unconscious position is that of a child. Thus, spirituality in children does not differ in its structure from that of adults, but only in its manifestation, which is why children have the right to be heard as independent persons regarding their beliefs.

\section{Final considerations}

Based on the understanding that a spiritual aspect is an intrinsic part of the pediatric patient, it is essential that experts in palliative care, as well as in general pediatrics and in various specialties, such as oncologists, haematologists and neonatologists, effectively exercise this care, based on a knowledge of the needs of children and their families and on the recognition of the importance of a multi and inter-disciplinary work, for the personalised and comprehensive care of each patient ${ }^{6}$.

Thus, the pedagogical model of medical schools, based on scientific rationalism, need to be reviewed. This is the challenge to be faced by medical schools: establishing curriculum guidelines according to the Cartesian-Flexerian model, or train a professional who understands and can integrate the biological, psychological, social and spiritual factors related to diseases ${ }^{10}$. Introducing this theme throughout medical training, specifically of pediatricians, is a real and absolute necessity, which will benefit all staff involved, and especially the patients, by providing a dignified end-of-life and death ${ }^{6}$.

\section{Referências}

1. Batista KT, Seidl EMF. Estudo acerca de decisões éticas na terminalidade da vida em unidade de terapia intensiva. Com Ciências Saúde. 2011;22(1):51-60.

2. Lago PM, Garros D, Piva JP. Terminalidade e condutas de final de vida em unidades de terapia intensiva pediátrica. Rev Bras Ter Intensiva. 2007;19(3):359-63.

3. Peres MFP, Arantes ACLQ, Lessa PS, Caous CA. A importância da integração da espiritualidade e da religiosidade no manejo da dor e dos cuidados paliativos. Rev Psiq Clin. 2007;34(1):82-7.

4. Santos RZ. A espiritualidade e a religiosidade na prática pediátrica [dissertação]. Sorocaba: Pontifícia Universidade Católica de São Paulo, Faculdade de Ciências Médicas e da Saúde; 2013.

5. Maciel MGS, Rodrigues LF, Naylor C, Bettega R, Barbosa SM, Burlá C et al. Critérios de qualidade para os cuidados paliativos no Brasil: documento elaborado pela Academia Nacional de Cuidados Paliativos. Rio de Janeiro: Diagraphic; 2006. p. 8-9.

6. Valadares MTM, Mota JAC, Oliveira BM. Cuidados paliativos em pediatria: uma revisão. Rev. bioét. (Impr.). 2013;21(3):486-93.

7. Conselho Federal de Medicina. Resolução CFM no 2.005, de 9 de novembro de 2012. Dispõe sobre a nova redação dos Anexos II e III da Resolução CFM no 1.973/2011, que celebra o convênio de reconhecimento de especialidades médicas firmado entre o Conselho Federal de Medicina (CFM), a Associação Médica Brasileira (AMB) e a Comissão Nacional de Residência Médica (CNRM). [acesso 11 jun 2015]. Disponível: http://bit.ly/1RhUhNd

8. Academia Nacional de Cuidados Paliativos. O que são cuidados paliativos? [acesso 11 de jun 2015]. Disponível: http://www.paliativo.org.br/ancp.php? p=oqueecuidados

9. Toledo AP, Priolli DG. Cuidados no fim da vida: o ensino médico no Brasil. Rev Bras Educ Med. 2012;36(1):109-17.

10. Souza VCT, Pessini L, Hossne WS. Bioética, religião, espiritualidade e a arte do cuidar na relação médico-paciente. Revista Bioethikos. 2012;6(2):181-90.

11. Tavares CQ. Espiritualidade e bioética: prevenção da "violência" em instituições de saúde. Rev Pistis Prax Teol Pastor. 2013;5(1):39-57. 
12. Vasques RCY, Bousso RS, Mendes-Castillo AMC. A experiência de sofrimento: histórias narradas pela criança hospitalizada. Rev Esc Enferm USP. 2011;45(1):122-9.

13. Gentil RC, Guia BPG, Sanna MC. Organização de serviços de capelania hospitalar: um estudo bibliométrico. Esc Anna Nery Rev Enferm. 2011 jan-mar; 15(1):162-70.

14. Francisco DP, Costa ICP, Andrade CG, Santos KFO, Brito FM, Costa SFG. Contribuições do serviço de capelania ao cuidado de pacientes. Texto Contexto Enferm. 2015 jan-mar;24(1):212-9.

15. Lucas MFM. Espiritualidade na criança. Servir. 2008;56(2):90-6.

16. Mota SG. As fronteiras da fé na criança: descobrindo as relações socio-religiosas da espiritualidade infantil [TCC]. São Paulo: Universidade Metodista; 2005.

17. Freud S. Obras psicológicas completas de Sigmund Freud, vol. 21. Rio de Janeiro: Imago; 1974. 0 futuro de uma ilusão, p. 15-74.

18. Freud S. Op. cit, vol. 24. Rio de Janeiro: Imago; 1974. Moisés e o monoteísmo, p. 16-164.

\section{Participation of the authors}

Marlene Pereira Garanito contributed the manuscript drawing and design, together with Marina

Rachel Graminha Cury, participated in the preparation and critical review of the text and approved the final version.

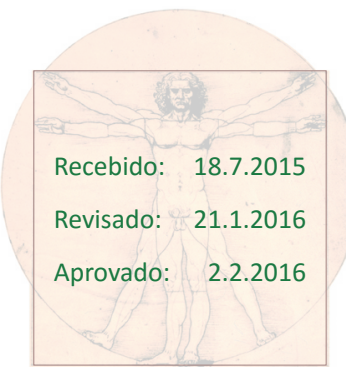

